\title{
簡易型小型漁礁の有効性と藻場再生の 検証試験
}

\author{
後藤＼cjkstart益滋 1 \\ 1 正会員 学校法人香川学園 宇部環境技術センター \\ （干755-8551 山口県宇部市文京町 4-23） \\ E-mail: gotou@ukgc-eco.ac.jp
}

\begin{abstract}
本研究は，近年各地で確認されている海藻群落が消失する磯やけ現象によって衰退している沿岸生態系 の保全及び再生を目標に簡易的でかつ浅海域においても設置可能な小型漁礁を開発することを目的とし た．格子状に設計した鋳鉄製の枠を組み立てて，既存の藻場への影響を考慮して， L.W.L - 2.0m の砂地に 設置した．設置方法の検討として，非固定，鉄筋棒による固定の条件を検討した。

設置後の海藻の繁茂状況や，生物の蝟集状況の変遷についてモニタリングを行った結果，試験中にホン ダワラ類といった大型海藻の繁茂は確認されなかったが，小型海藻の繁茂は確認された。また，貝類，甲 殼類, 魚類の幼魚または底魚が確認され, 周辺の藻場群落とほとんど遜色の無い効果が認められた。
\end{abstract}

Key Words : gin block fishing reef, biomass at fishing reefs

\section{1. 本研究の目的}

浅海域は，非常に生産性の高い地域である，特に，海 藻が繁茂している藻場や沿岸の一次生産の場であるとと もに，海生生物の産卵場，生息場にとって重要な水域で

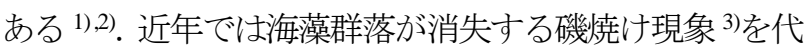
表とする環境変動が浅海域の生態系を著しく衰退させ, その対策が急務となっている．単純に藻場が喪失すると いう事象ではなく，藻場の喪失の影響は海藻の葉上を利 用する生物の生息場や魚類その他生物の餌場，産卵場や 幼体の逃避場としての機能を一気に失うことで，その海 域の生産性を著しく低下させてしまう可能性が非常に高 い：そうした状況を改善する方策として，各地で食害の 防除，蓄磯，藻礁の設置等さまざまな活動が行われ 4 , それに併せて, 海藻の養生や水産有用種の放流なども行 われている5)

しかしながら，これらは設置費用や本体そのものが非 常に巨大化する傾向にあるために浅海域では容易に組み 立て，設置することが難しいことが挙げられる ${ }^{9}$. 本研 究では，容易に組み立てや設置が可能であること，様々 な海底形状に柔軟に対応できること，安価であることを 主眼に置き，小型でかつ軽量な浅海域特化型漁礁の開発 とその有効性及び設置方法について検討を行ったことを 報告する.

\section{2. 研究の内容}

本漁礁の素材は，加工と鋳造が容易でかつ単価の安い 鋳鉄とした. 形状は, 約 $4 \mathrm{~cm} \times 4 \mathrm{~cm}$ 格子を設けた $30 \mathrm{~cm}$ $\times 30 \mathrm{~cm}$ の正方形のプレートを6面の縁をボルトで固定 するとキューブ状となり非常に簡素な構造体となる（写 真-1)。これは現場での組み立て，設置を容易にするため である. 重量は, 約30 kgであるために船上及び陸上から の投入が可能である。本漁礁の実証試験は，図-1に示す 山口県下関市阿川地先海域に設置した。本漁礁設置の際

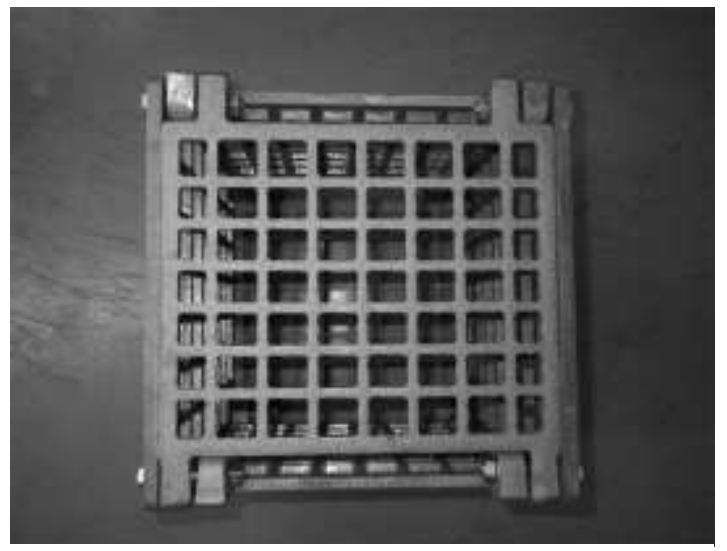

写真-1＼cjkstart鉄枠漁礁の構造 
にその内部には，図-2に示すフライアッシュをポリアク リルアミド：ハリマ化成製（以下，バインダー）で固化 させた小型プレート $(10 \mathrm{~cm} \times 10 \mathrm{~cm})(\mathrm{B})$, フライアッシュ +粉末小炭をバインダーで固化させた小型プレート(10 $\mathrm{cm} \times 10 \mathrm{~cm})(\mathrm{C})$ 及び大型プレート $20 \mathrm{~cm} \times 20 \mathrm{~cm}(\mathrm{D})$ に穴を 開けて，鉄筋棒に通したものを鉄体格子に固定して設置 した. (B), (C)については，プレートとプレートの間に 約 $4 \mathrm{~cm}$ の隙間を設けた. ブランク (A)にはキューブの内部 に何も設置しなかった.

B及びC，Dプレートの性状の違いは，色による生物ま たは藻類の蝟集, 着生の選好性に着目し, その効果を確 認することである. また，様々な形状，規格のプレート を設置した理由は，間隙を創出することで，そこを生息 する生物の誘因効果を検証するものである.

設置場所は，リーフ状となった内湾になっており，ガ ラモ場及びカジメ場が点在する岩礁または砂地である. 水深は, L.W.Lから-1.5 3.0 mであり, 近年は藻場が消失 する磯燒け現象が確認される. 本検証実験では, 岩礁の 間に点在する砂地(L.W.L-2.0付近)を設置場所として選定 した．また，外力による転倒，移動などの影響に対する 措置は特段行わず2011年12月5日に本漁礁を船上から投 入した，その間隔は約 $2 \mathrm{~m}$ とした. 設置後の変化につい て，スキューバ潜水によって蝟集する魚種及びその他海 生動物の潜水目視観察を行った. 海澡類については $5 \mathrm{~cm}$ $\times 5 \mathrm{~cm}$ の永久コドラートを設置し, 被覆率を記録した. また, 鉄枠(A), 性状が異なる素材 $(\mathrm{B} \sim \mathrm{D})$ で作成したプレ 一トの表面に付着する藻類を把握するために, 永久コド ラートとは別に $3 \mathrm{~cm} \times 3 \mathrm{~cm}$ 四方をマイクロファイバー クロスで表面採取し量的指標となるクロロフィルaを測 定した.これは, 検証する構造物や基材の種類によって,

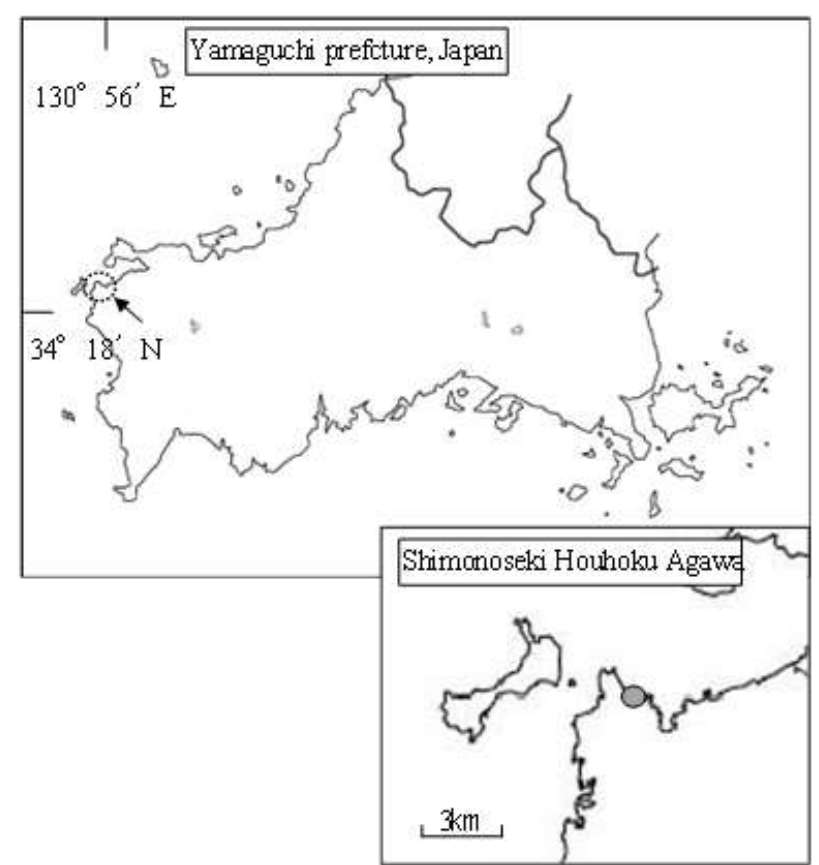

図-1 実証試験の実施場所

海藻よりもさらに微細な藻類の着生状況の多寊を検証す るためである. 海藻類の着生基盤または海藻の葉上には 様々な微細藻類も繁茂しており，それを餌料として利用 する生物も多いためである.

比較対象として，対照地点を3箇所(砂地E，岩盤F，磯 焼けが起きている岩盤G)にロープをアンカーで固定し た永久コドラート $(30 \mathrm{~cm} \times 30 \mathrm{~cm})$ を設置し, 同様の調 査を実施した。 なお，岩盤Fは，大型海藻のホンダワラ 類, 主としてヨレモク, カジメといった多年性海藻から1 年生海藻であるアカモク, ワカメが繁茂する海域である. GはFとほぼ同じ岩盤であるが, 磯やけが進行している区

(A)

(C)

Blank
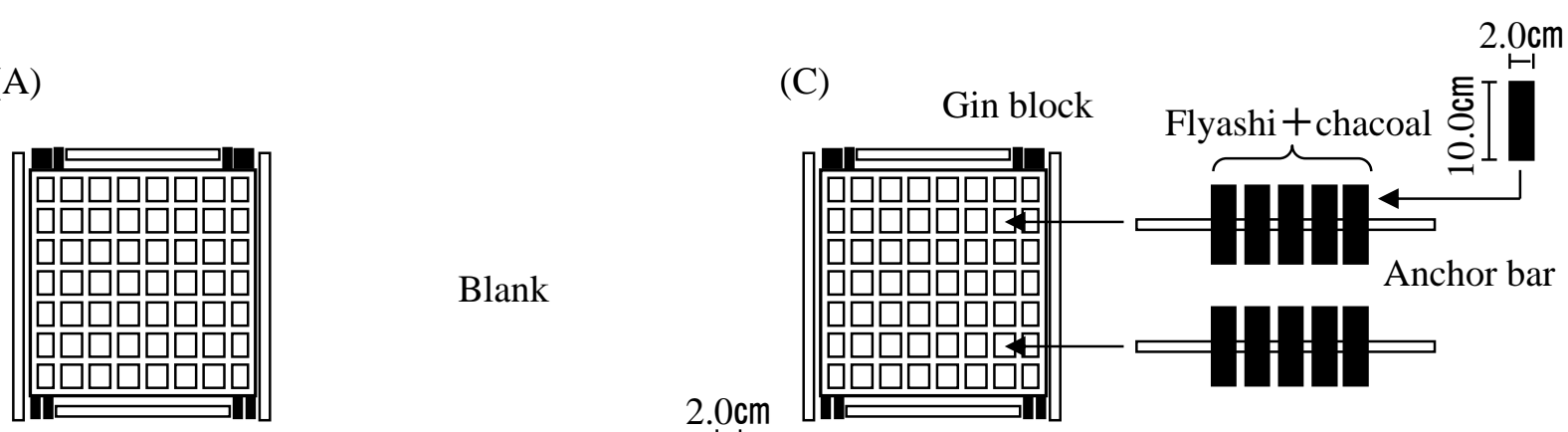

(B)
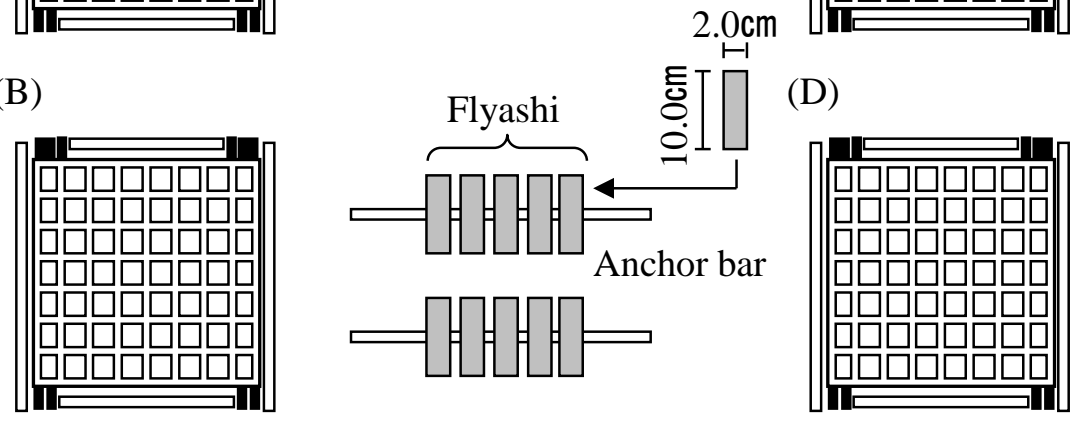

Flyashi + chacoal

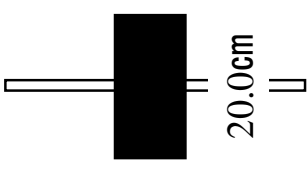

$10.0 \mathrm{~cm}$

図-2 漁礁内包物の構造 $(\mathrm{A} \sim \mathrm{D})$ 

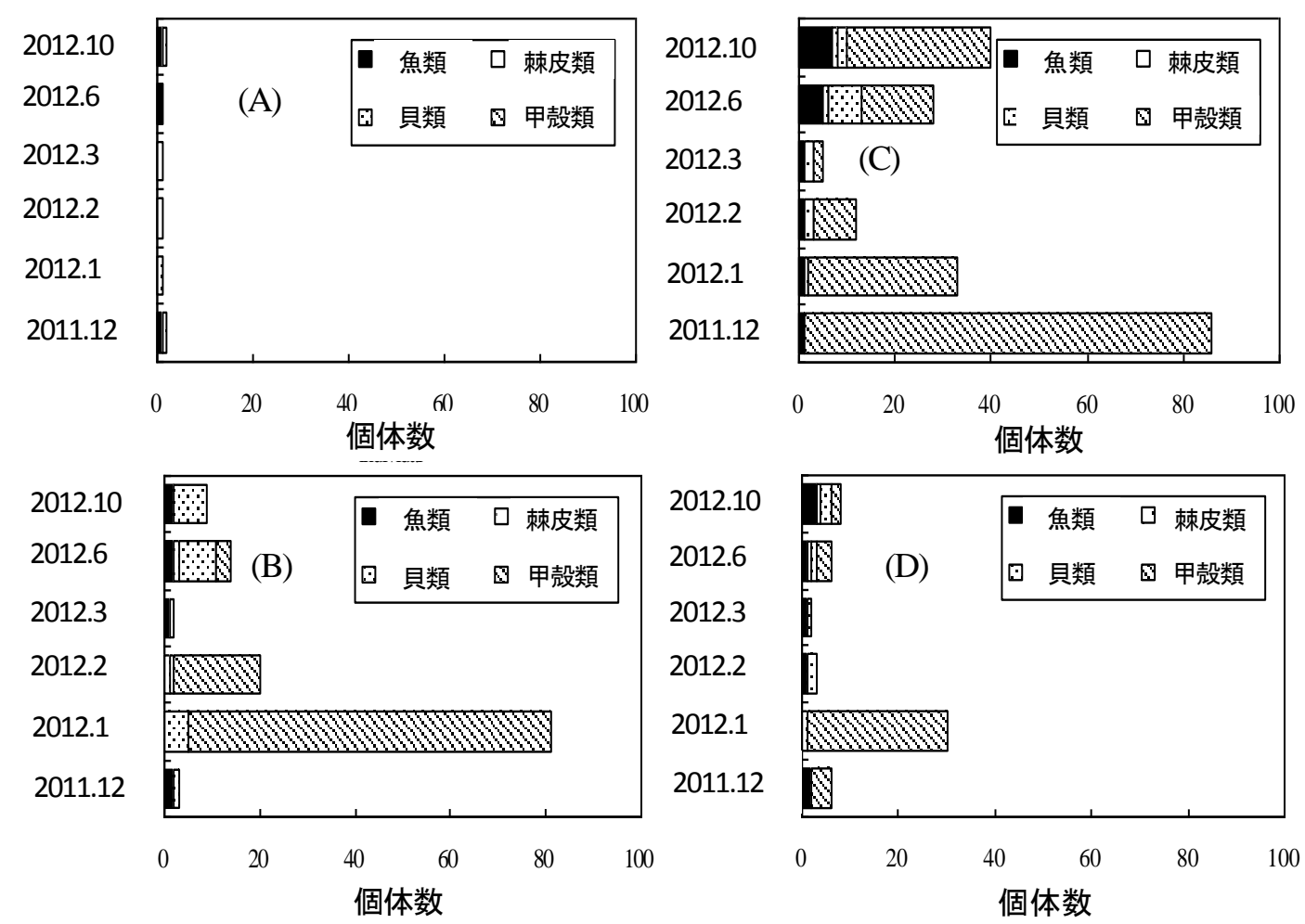

図-3＼cjkstart蝟集する動物の季節変動（A～D）
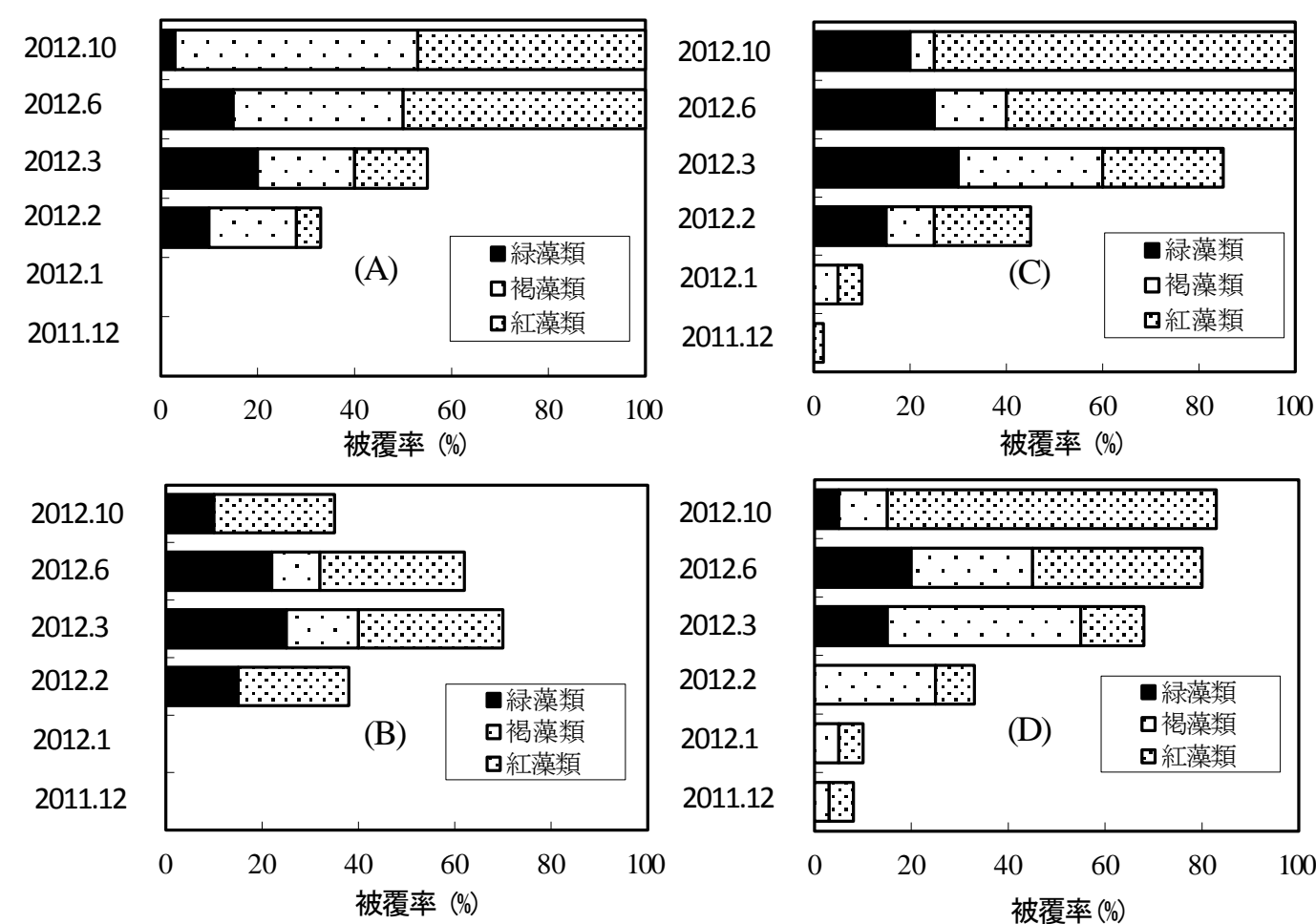

図-4＼cjkstart藻類の被覆率の季節変動（A〜D）

域であり，大型海藻は確認されず，マクサ等の小型海藻 がまばらに確認される程度である。

\section{3. 結果と考察}

\section{（1）蝟集する動物の季節変動}

本漁礁の効果についてその時系列変化を図-3 に示す. 設置後， 2 週間後に行った調査では小型プレートを挿入 した B 及びC にはプレートの間隙に甲殼類を最大で 85 個体(B)確認できた，その他，ウ二，ナマコを代表とする 棘皮類及び貝類を多く確認できた. 表-1 に示す A の主な 
出現種は，枠内に内包物がないため，マナマコ，イトマ キヒトデといった海底を這う生物が多く確認された. C, $\mathrm{D}$ は，コシマガリモエビが占めることが多く，主に枠内 に設置したプレートの間隙中に付着していた. B, Cは, プレートの性状が異なる以外はほぼ同じ規格で設置して いるにも関わらず， B は主な出現種の変遷が目立った.

C，Dは，性状が同じであるが規格が異なるため, 出現 傾向が異なるものと推察されたが，ほぼ同じような傾向 で推移しているため, 濃色への選好性が考えられる. 個 体数は，枠内部に何も入れない $\mathrm{A}$ （Blank）は，B～C と 比較すると，枠内が空洞であるため，確認できる種類は 少ない，いずれにしても，本漁礁に内容物を内包する方 が甲殼類，ウニ、貝類への効果の向上が窥われた. 魚類 は，表-2に示寸カサゴ，ホシササノハベラなど，6種類 確認され，プレートの間隙や，底面で確認された。 既往 報告との比較においても設置水深が異なり単純比較はで きないものの, 効果は本漁礁のように小規模構造体でも 十分機能することが明らかとなった ${ }^{7)}$. また，投入する 海底基盤は，砂地であることから，波浪による外力によ って転倒などの影響が考えられたが, 次第に砂で埋没し, 移動や転倒などは確認されなかった. 砂地での検証では, 元々単調であること, 後述の対象地点 $\mathrm{E}$ における結果で も述べているように生物相も貧弱であり, 本漁礁のよう な小型の構造物を投入するだけで大きく変化することが 明らかとなった．また，F とほぼ同じ傾向であることか ら, 海藻群落の代替として機能も期待できることも考え られた.

\section{（2）鉄枠表面の藻類の被覆率の季節変動}

図-4 に示寸構造体の上面 $(30 \mathrm{~cm} \times 30 \mathrm{~cm})$ に被覆する 海藻類は, 刘照地点に繁茂しているカジメ, ホンダワラ 類といった大型海藻は確認されなかったが，表-3に示す マクサ，オバクサ紅藻類や褐藻類のウミウチワといった 海藻群落の下層域を構成する種で占められており, 経過 を追うごとに被覆率は増加傾向を示した．設置功 11 ケ月後の 2012 年 10 月には A, C の被覆率が 100\%とな り，D被覆率も 80\%の被覆率 (2012 年 10 月) となっ た. B は, 2012 年 3 月に被覆率が 70\%になったのを境に 減少傾向を示した。これは, 枠表面の鋳鉄が腐食によっ て剥離したためである.

\section{（3） 対照地点 E，F，Gの動物の季節変動}

図-5（左図）に示寸 E は，砂地であるため確認される 生物種は少なく, 10 個体前後で推移していた. そのうち, 魚類はクサフグの 1 種類であり, 主に確認されるのはキ サゴ（貝類）であった。

図-5（右図）に示寸 F は，クロメ，ヨレモクなどの大 型海藻が衰退期の 6,10 月を除き，ほぼ 1 年中確認され
表-1 優占種（甲殼類，棘皮類，貝類）

\begin{tabular}{|l|l|l|l|l|}
\hline \multirow{2}{*}{ 年月 } & \multicolumn{4}{|c|}{ 優占種 } \\
\cline { 2 - 5 } & \multicolumn{1}{|c|}{$\mathrm{A}$} & \multicolumn{1}{|c|}{$\mathrm{B}$} & \multicolumn{1}{c|}{$\mathrm{C}$} & \multicolumn{1}{c|}{$\mathrm{D}$} \\
\hline 2011.12 & マナマコ & マダコ & コシマガリモエビ & コシマガリモエビ \\
\hline 2012.1 & テングニシ & コシマガリモエビ & コシマガリモエビ & コシマガリモエビ \\
\hline 2012.2 & イトマキヒトデ & ホンヤドカリ属 & ホンヤドカリ属 & コシダカガンガラ \\
\hline 2012.3 & イトマキヒトデ & トラフナマコ & ホンヤドカリ属 & コシダカガンガラ \\
\hline 2012.6 & 該当種なし & コシダカガンガラ & ホンヤドカリ属 & ホンヤドカリ属 \\
\hline 2012.10 & トラフナマコ & チグサガイ & タテジマフジボ & コシマガリモエビ \\
\hline
\end{tabular}

表-2 優占種 (魚類)

\begin{tabular}{|c|c|c|c|c|}
\hline \multirow{2}{*}{ 年月 } & \multicolumn{4}{|c|}{ 優占種 } \\
\hline & A & B & $\mathrm{C}$ & $\mathrm{D}$ \\
\hline \multirow{2}{*}{2011.12} & \multirow{2}{*}{ 該当種なし } & ホシササノハベラ & \multirow{2}{*}{ アナ八ゼ } & \multirow{2}{*}{ アナハゼ } \\
\hline & & ヒガンフグ & & \\
\hline 2012.1 & 該当種なし & 該当種なし & カサゴ & カサゴ \\
\hline 2012.2 & 該当種なし & 該当種なし & カサゴ & カサゴ \\
\hline 2012.3 & 該当種なし & ホンベラ & カサゴ & 該当種なし \\
\hline 2012.6 & クサフグ & クサフグ & カサゴ & カサゴ \\
\hline \multirow{2}{*}{2012.10} & \multirow{2}{*}{ クサフグ } & カミナリベラ & \multirow{2}{*}{ ククリグ } & \multirow{2}{*}{ クサフグ } \\
\hline & & サビ八ゼ & & \\
\hline
\end{tabular}

表-3 優占種（海藻類）

\begin{tabular}{|c|c|c|c|c|}
\hline \multirow{2}{*}{ 年月 } & \multicolumn{4}{|c|}{ 優占種 } \\
\hline & A & B & $\mathrm{C}$ & $\mathrm{D}$ \\
\hline 2011.12 & 該当種なし & 該当種なし & マクサ(紅藻) & マクサ(紅藻) \\
\hline 2012.1 & 該当種なし & 該当種なし & マクサ(紅藻) & マクサ(紅藻) \\
\hline 2012.2 & ウミウチワ(褐藻) & マクサ(紅藻) & マクサ(紅藻) & ウミウチワ(褐藻) \\
\hline \multirow{3}{*}{2012.3} & \multirow{3}{*}{ ウミウチワ(褐藻) } & \multirow{3}{*}{ マクサ(紅藻) } & マクサ(紅藻) & \multirow{3}{*}{ |ウミウチワ (褐藻) } \\
\hline & & & ウミウチワ(褐藻) & \\
\hline & & & リボンアオサ(緑藻) & \\
\hline \multirow{2}{*}{2012.6} & \multirow{2}{*}{ マクサ(紅藻) } & \multirow{2}{*}{ マクサ(紅藻) } & マクサ(紅藻) & \multirow{2}{*}{ マクサ(紅藻) } \\
\hline & & & オバクサ(紅藻) & \\
\hline \multirow{2}{*}{2012.10} & マクサ(紅藻) & \multirow{2}{*}{ マクサ(紅藻) } & マクサ(紅藻) & マクサ(紅藻) \\
\hline & ウミウチワ(褐藻) & & オバクサ (紅藻) & オバクサ(紅藻) \\
\hline
\end{tabular}

ることから，岩盤，海藻の葉上に甲殼類の割合が大きか った．優占種は，本漁礁で確認される種とほぼ同じであ り，コシマガリモエビ（甲殼類）及びコシダカガンガラ

（貝類）であった．図-6 に示す $\mathrm{G}$ は大型海藻が存在せ ず， $\mathrm{E}$ と同じく単調な環境となるため, 生物相が小さく なっていることが窥われる. よって, 結果を整理すると, $\mathrm{E}$ のような環境における生物相は単調あること, $\mathrm{G}$ のよ うに後発的な海藻の消失によって葉上やその周辺域に生 息する生物相の衰退を引き起こしていることを踏まえる と，本漁礁を設置する際には， $\mathrm{E} や \mathrm{G}$ のような環境では 本漁礁を設置することによって動物の生息環境の修復効 果が期待できる可能性が示唆される.

\section{（4） 構造体及び基材表面のクロロフィル a}

構造体や基材の違いによる海藻よりもさらに微細な付 着藻類の着生効果を狙った検証試験の結果を図-7に示す. 設置後からの変動は，設置直後の 2011 年 12 月から認め られ, 時間経過とともに上昇傾向を示した. B は $2.0 \mu \mathrm{g} / \ell$ 程度小さくなる傾向を示したが，構造体や基材の違いに 大差はなかったことから，素材の違いによる付着基盤の 選好性は認められないものと推察される. 

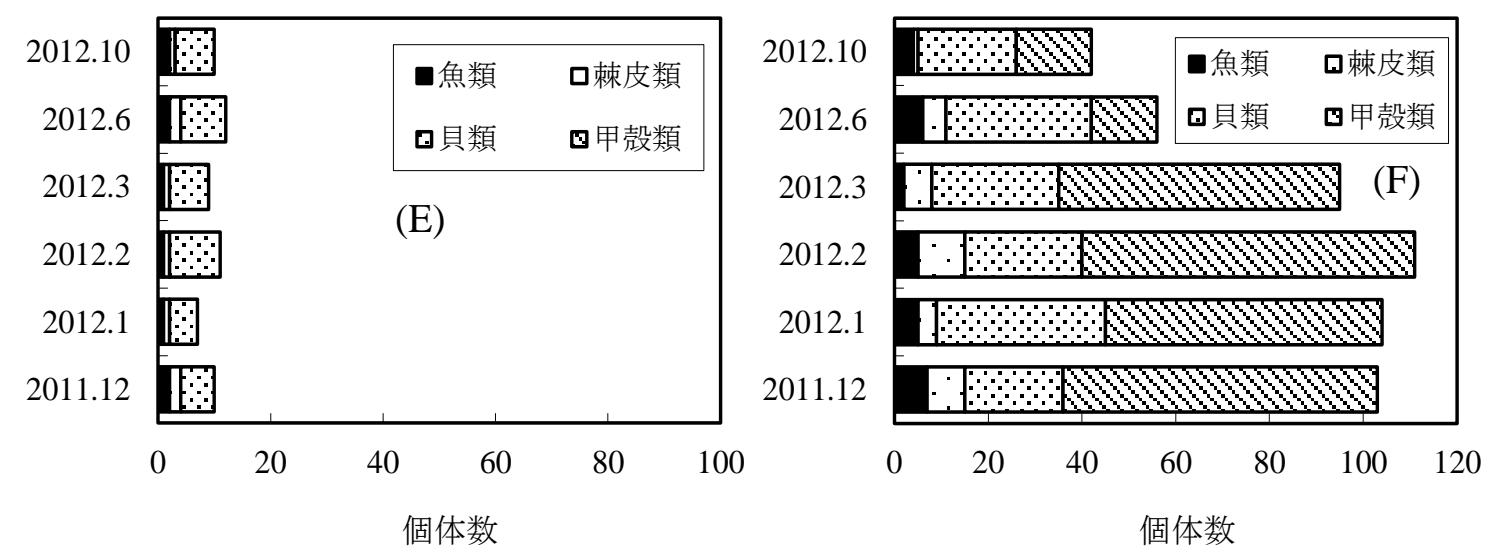

図-5 E,F の季節変動（動物）

\section{4. 結論}

\section{（1）蝟集する動物の季節変動}

本漁礁の効果について，投入する海底基盤は，砂地で あることから，波浪による外力によって転倒などの影響 が考えられたが，次第に砂で埋没し，移動や転倒などは 確認されなかった。砂地での検証では，元々単調な環境

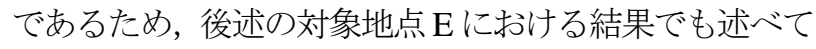
いるように生物相も貧弱であり, 本漁礁のような構造物 を投入するだけで大きく変化することが明らかとなった. また，Aのように構造体の内包物が存在しないよりも， $\mathrm{B} \sim \mathrm{D}$ のように基材を内包し，間隙を創出することで， 海藻群落の代替として機能も期待できることが判明した.

\section{（2）鉄枠表面の藻類の被覆率の季節変動}

本漁礁では, 対照地点に繁茂しているカジメ, ホンダ ワラ類といった大型海藻が確認されなかったものの, マ クサ，オバクサ紅藻類や褐藻類のウミウチワといった海 藻群落の下層域を構成する種が経過を追うごとに被覆率 の増加傾向を示した.

\section{（3）対照地点 E，F，G の動物の季節変動}

$\mathrm{E}, \mathrm{G}$ は単調な環境となるため, 生物相が小さくなっ ていることが窥われる．よって，Gのように後発的に引 き起こされた海藻群落の消失は葉上やその周辺域に生息 する生物相の衰退をも引き起こしているため，本漁礁を 設置する際には， Eや G のような環境に設置することに よって動物の生息環境の修復効果が期待できる可能性が 示唆される.

\section{（4）構造体及び基材表面のクロロフィル a}

構造体や基材の違いによる海藻よりもさらに微細な 付着藻類の着生効果については, 設置直後の 2011 年 12 月から認められ, 時間経過とともに值の上昇傾向を示し た. B は $2.0 \mu \mathrm{g} / \ell$ 程度小さくなる傾向を示したが, 構

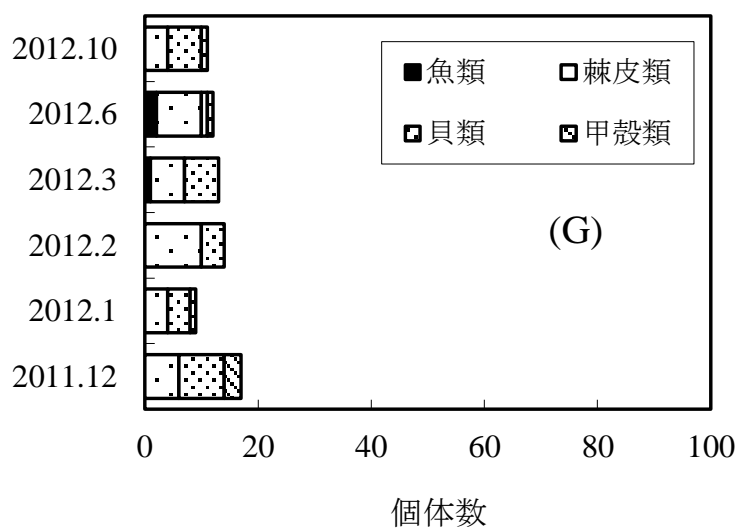

図-6 G の季節変動（動物）

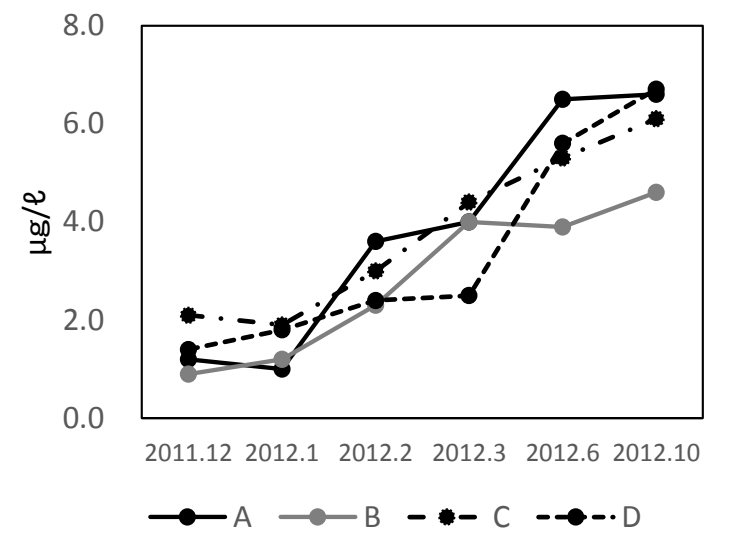

図-7＼cjkstart構造体及び基材表面のクロロフィル a

造体や基材の違いに大差はなかったことから，付着基盤 の選好性は認められないものと推察される.

謝辞 : 山口県漁協阿川支店の諸氏には本研究のフィール ド提供及び調查協力に多大な尽力を頂いた。ここに感謝 の意を表します。

\section{参考文献}

1) 野村浩貴ら : 北海道南西部海岸における潮下帯海藻お 
よび底生動物群集の季節的変遷, 海生研報, 第 3 報 , $1-12,2001$

2) 上出貴士ら: 和歌山県田辺湾の潮間帯におけるコアマ モ群落の甲殼類群集構造, 水産増殖, 59(3)，351-361， 日本水産増殖学会, 2011 .

3) 藤田大介：磯焼けの現状，水産工学，39(1)，41-46, 日本水産工学会, 2002 .

4) 田中敏博:南日本における磯焼けと藻場回復(平成 17 年度日本水産工学会春季シンポジュウム「磯焼け対策 を考える〜魚類による過剰食圧の軽減に向けて〜」), 水産工学 43(1), 47-52, 2006.
5) 桐原慎二, 藤川義一 : 青森県尻屋の漁業者ダイバーに よる磯焼け域におけるコンブ群落回復の試み(平成 21 年度日本水産工学会秋季シンポジウム「持続的な磯焼 け対策の実践に向けて」) 水産工学 48(1), 29-34, 2011.

6) 日本大型漁礁協会: http://www. nissyoukyou.com/ichiran 01.html.

7) 森脇晋平ら:島根県浜田沖に沈設された高層漁礁にい 集する魚類の経年変動，島水試研報 12，1～6, 2005.

\section{STUDY ON OF VERIFICATION TEST OF GIN BLOCK FISHREEF}

\section{Masuji GOTO}

The aim of this study is to utilization substitute and reproduction by a seaweed flora damage, a decline of the fauna on the seaweed. This study on artificial fish reef use a gin block $(30 \mathrm{~cm} \times 30 \mathrm{~cm})$, four experience plate(Fig.3,Blank(no plate),flyashi $(4 \mathrm{~cm} \times 4 \mathrm{~cm}: B)$, flyashi and charcoal $(4 \mathrm{~cm} \times 4 \mathrm{~cm}: C)$, flyashi and charcoal $(10 \times 20: D))$ is disposed inside the inter frame and fixed at $4 \mathrm{~cm}$ of intervals(C,D).

This fish reef, $B$ and $C$ have much biomass, approximately equal to a contrast point $(F, G)$, an attached algal coating rate, increased with progress of the time, not the fall, too. It was revealed that the artificial fishing bank sufficiently functioning as a fishing bank in an early stage after being sunk in water. 